JEMS (Jurnal Edukasi Matematika dan Sains), 8(1), 2020, 69-78

DOI: $10.25273 /$ jems.v8i1.6088

\title{
Efektivitas Problem Based Learning dan Problem Solving Ditinjau dari Kemampuan Pemecahan Masalah Matematika Peserta Didik Kelas IV SD
}

\author{
Ulva Amalia Putri, Wahyudi
}

(C) 2020 JEMS (Jurnal Edukasi Matematika dan Sains)

This is an open access article under the CC-BY-SA license (https://creativecommons.org/licenses/bysa/4.0/) ISSN 2337-9049 (print), ISSN 2502-4671 (online)

\begin{abstract}
Abstrak:
Penelitian ini memiliki tujuan untuk mengetahui perbedaan efektivitas model Problem Based Learning dan Problem Solving terhadap kemampuan pemecahan masalah matematika peserta didik kelas IV SD. Penelitian ini termasuk penelitian eksperimen semu dengan populasi Gugus Kartini di Kecamatan Bergas. Sampel yang diambil pada penelitian ini yaitu 28 peserta didik SDN Bergaskidul 03 sebagai kelas eksperimen menggunakan dengan model PBL dan 21 peserta didik SDN Bergaskidul 04 sebagai kelas kontrol yang menggunakan model PS. Teknik pengambilan data yang dilakukan yaitu observasi dan tes. Hasil uji prasyarat menunjukkan data yang diperoleh berdistribusi normal dan homogen. Selanjutnya dilakukan analisis uji T menggunakan Independent Sample T-test diperoleh hasil 0,01 sehingga $\mathrm{H}_{0}$ ditolak dan $\mathrm{H}_{a}$ diterima yang artinya terdapat perbedaan efektivitas dari kedua model. Tingkat keefektivan kedua model dilihat dari hasil uji N-Gain yang menunjukkan bahwa kelas eksperimen mengalami peningkatan 0,3714 dalam kategori sedang dan kelas kontrol mengalami peningkatan sebesar 0,3052 dalam kategori sedang. Kedua model mengalami peningkatan dalam kategori sedang, namun peningkatan lebih tinggi terjadi pada kelas eksperimen sehingga dapat diketahui bahwa model pembelajaran PBL lebih efektif untuk meningkatkan kemampuan pemecahan masalah daripada model PS.
\end{abstract}

Kata Kunci: Problem Based Learning, Problem Solving, Kemampuan Pemecahan Masalah.

\begin{abstract}
:
This research aims to determine the effectiveness of the Based Learning models and Problem Solving models for the ability to solve mathematics problem on 4th students. This research includes a quasi-experimental study with the Kartini group population in Bergas sub-district. The samples taken in this study were 28 students at SDN Bergaskidul 03 as an experimental class using the PBL model and 21 students at SDN Bergaskidul 04 as a control class using the PS model. The technique of capturing data is observation and tests. The prerequisite test shows both homogeneous and normally distributed. Then $\mathrm{T}$ test analysis obtained results 0.01 so $\mathrm{H}_{\mathrm{o}}$ rejected and $\mathrm{H}_{\mathrm{a}}$ accepted which means there is a difference in effectiveness of both models. The effectiveness level of both models is seen from the N-Gain test results indicating that the experiment class has increased 0.3714 in the medium category and the control class has increased by 0.3052 in the medium category. Both models experienced an increase in the medium category, but a higher increase in the experiment class made it possible for the PBL learning model to be more effective for improving problem solving capabilities than PS models.
\end{abstract}

Keywords: Problem Based Learning, Problem Solving, Problem Solving Skill

\section{Pendahuluan}

Pendidikan merupakan usaha yang dilakukan untuk mewujudkan kemampuan individu melalui proses pembelajaran yang aktif dan memberi keteladanan dengan melibatkan interaksi

Ulva Amalia Putri, Universitas Kristen Satya Wacana

Amaliaulva07@gmail.com

Wahyudi, Universitas Kristen Satya Wacana

yudhi@staff.uksw.edu 
individu dan lingkungannya (Arifin, 2014 dan UU No. 20 Tahun 2003). Proses pembelajaran yang dirancang harus memungkinkan peserta didik memperoleh pengalaman belajar, namun pembelajaran saat ini masih menekankan peran guru yang menjelaskan untuk menyelesaikan materi kemudian peserta didik dituntut menghafal konsep itu secara individual (Faizah, 2015). Pembelajaran yang kurang memberikan kesempatan dalam mengemukakan ide untuk menyelesaikan jawaban dan memahami materi sehingga peserta didik pasif merupakan pembelajaran yang bersifat teacher centered (Haji, 2010). Pembelajaran tersebut kurang sesuai dengan tuntutan dalam UU No. 20 Tahun 2013, yang menekankan suasana dan proses pembelajaran dimana peserta didik dituntut untuk aktif mengembangkan potensi dirinya. Selain itu pembelajaran tersebut tidak sesuai dengan paradigma belajar yang benar karena belajar adalah suatu aktivitas untuk memperoleh pengetahuan, meningkatkan ketrampilan, memperbaiki perilaku sikap, dan mengokohkan kepribadian (Suyono, 2015). Apabila guru terus melaksanakan pembelajaran tersebut dikhawatirkan tidak dapat memenuhi tuntutan pembelajaran kekinian untuk memiliki kemampuan 4C (Communication, Collaboration, Critical Thinking and Problem Solving, dan Creativity and Innovation), berkarakter, dan memiliki pemikiran tingkat tinggi atau yang disebut HOTS (High order thinking skill) dengan tujuan memberikan kebermakanaan pembelajaran. Menciptakan proses pembelajaran yang dapat memenuhi tuntutan tersebut menjadi tantangan bagi seorang guru. Alternatif yang dapat dilakukan dalam mewujudkannya yaitu mengaitkan pembelajaran dan pengalaman atau permasalahan peserta didik sehari-hari. Guru sebagai pelaksana pembelajaran harus bisa merancang model pembelajaran yang tepat agar dapat memenuhi tujuan tersebut.

Model pembelajaran digunakan untuk merancang pembelajaran dalam jangka panjang, mulai dari merancang bahan, pelaksanaan, dan membimbing pembelajaran yang dilakukan (Joyce \& Weil (dalam Rusman, 2012)). Seiring perubahan kurikulum penggunaan model, metode, dan sumber belajar harus disesuaikan dengan karakteristik peserta didik di tiap mata pelajaran dan tentunya dapat memfasilitasi peserta didik terlibat langsung (Permendikbud No 22 Tahun 2016). Sesuai dengan tuntutan Permendikbud tersebut sangat disarankan penerapan model pembelajaran menggunakan: (1) model pembelajaran berbasis penyingkapan/penelitian (discovery learning/inquiri), (2) model pembelajaran berbasis masalah (problem based leaning), dan (3) model pembelajaran berbasis proyek (project based learning).

Model pembelajaran berbasis masalah (Problem Based Learning) melatih peserta didik memecahkan masalah menggunakan masalah konkret sebagai konteks untuk belajar, sehingga memperoleh pengetahuan dan konsep yang esensial dari materi pelajaran (Nurhadi, 2003,). Selain model tersebut, pembelajaran berbasis masalah dikembangkan salah satunya yaitu model Problem Solving yang mengajarkan penyelesaian masalah dengan memberikan penekanan pada terselesaikannya suatu masalah secara menalar (Gulo, 2002). Kedua model pembelajaran memiliki kesamaan yaitu berbasis masalah dan pembelajaran yang dilakukan bertitik berat pada aktifitas peserta didik dalam memecahkanya, namun kedua model memiliki perbedaan dari penyajian pembelajaran yang dilakukan. Model Problem Based Learning terdiri dari lima langkah diantaranya: (1) orientasi peserta didik dalam masalah; (2) mengorganisasikan peserta didik untuk belajar; (3) membimbing pengalaman individual/kelas; (4) mengembangkan dan menyajikan hasil karya; (5) menganalisis dan mengevaluasi proses pemecahan masalah. Model Problem Solving juga memiliki lima tahapan yang berbeda diantaranya: (1) menentukan masalah; (2) mengumpulkan data; (3) menetapkan jawaban; (4) menguji kebenaran; (5) kesimpulan. Kedua model memiliki langkah pembelajaran yang berbeda tetapi sama-sama mengasah kemampuan 
peserta didik untuk memecahkan masalah karena masalah dijadikan point penting dalam pembelajaran.

Pembelajaran berbasis masalah mampu mengasah peserta didik untuk memecahkan masalah yang dasarnya merupakan tujuan utama proses pendidikan atau dapat dijadikan keberhasilan peserta didik dalam belajar (Dahar, 2011). Pemecahan masalah merupakan suatu usaha untuk menemukan jalan keluar dari suatu kesulitan atau masalah yang tidak biasa sehingga masalah tersebut tidak menjadi masalah lagi (Wahyudi dan Anugraheni, 2017).

Pemecahan masalah penting diajarkan karena diharapkan dapat memberi bekal peserta didik untuk memecahakan masalah baik secara teori atau praktik dalam kehiduan sehari-hari diantaranya dalam pembelajaran matematika karena setiap kegiatan manusia selalu berhubungan dengan matematika. Mata pelajaran matematika menerapkan pemikiran logika dalam poses berpikirnya dan berhubungan dengan serangkaian kegiatan manusia (Anugraheni, 2018). Sebagian objek kajian matematika bersifat abstrak dan sulit dipahami langsung oleh peserta didik salah satunya dalam materi penaksiran pecahan. Penyelesaian masalah pada materi tersebut memerlukan pemahaman mendalam dibandingkan materi lain. Untuk itu diperlukan suatu model pembelajaran berbasis pemecahan masalah dengan tujuan agar peserta didik memahami materi lebih mendalam. Indikator dalam pemecahan masalah menurut Polya (dalam Wahyudi dan Anugraheni, 2017) terdiri dari memahami masalah, merencanakan suatu penyelesaian, melaksanakan rencana penyelesaian, dan memeriksa kembali. Dilihat dari indikator tersebut sesuai dengan langkah model pembelajaran berbasis masalah dan diharapkan dapat menyelesaikan permasalahan yang telah disajikan. Sehingga proses pembelajaran dapat mencapai tujuan pembelajaran.

Penelitian dengan model pembelajaran Problem Based Learning dan Problem Solving telah dilakukan oleh beberapa peneliti diantaranya Nasir (2016) menyatakan bahwa model berbasis masalah (PBL) memberikan pengaruh terhadap kemampuan pemecahan masalah peserta didik sehingga dapat memperbaiki kemampuan tersebut. Sejalan dengan penelitian tersebut Indarwati, Wahyudi, \& Ratu, (2017) menyatakan bahwa melalui penerapan model Problem Based Learning dapat memberikan pengaruh kemampuan pemecahan masalah operasi hitung bilangan pecahan pada peserta didik. Disisi lain model pembelajaran Problem Solving memberikan dampak yang positif serta efektif terhadap kemampuan belajar matematika khususnya kemampuan pemecahan masalah matematis peserta didik (Hidayat dan Irawan, 2017). Penelitian yang telah dilakukan Astuti, (2018) menyatakan bahwa terdapat perbedaan efektifitas yang signifikan dalam penerapan model pembelajaran Problem Based Learning dan Problem Solving terhadap kemampuan berpikir kreatif matematika peserta didik. Penelitian ini membuktikan bahwa penerapan model Problem Based Learning lebih efektif terhadap kemampuan berpikir kreatif matematika yang diarahkan pemecahan maalah matematika pada peserta didik.

Penelitian yang dilakukan menyatakan bahwa penerapan model pembelajaran Problem Based Learning memberikan pengaruh kemampuan pemecahan masalah peserta didik pada mata pembelajaran matematika dan penggunaan model pembelajaran Problem Solving juga memperbaiki kemampuan dalam memecahkan masalah peserta didik. Kedua model pembelajaran yang berbasis masalah tersebut dinyatakan memberikan pengaruh terhadap kemampuan pemecahan masalah matematika peserta didik. Berdasarkan penelitian yang telah dilakukan terdapat keragu-raguan model pembelajaran mana yang lebih baik atau lebih memberikan pengaruh terhadap kemampuan pemecahan masalah sehingga penelitian ini melakukan eksperimentasi kedua model tersebut. Harapannya dari penelitian ini dapat berpengaruh terhadap keputusan menerapkan model pembelajaran yang baik. 


\section{Metode}

Jenis penelitian yang dilaksanakan adalah penelitian eksperimen dengan bentuk Quasi Experimental Design yang mempunyai kelas kontrol, tetapi tidak berfungsi sepenuhnya untuk mengontrol variabel-variabel luar yang mempengaruhi pelaksanaan eksperimen. Desain eksperiman dalam penelitian ini menggunakan Nonequivalent Control Group Design (Sugiono, 2012). Penelitian ini melihat seberapa besar perbedaan efektivitas setelah kedua kelas diberi perlakukan yang dapat dilihat pada table 1.

Tabel 1. Desain Nonequivalent Control Group Design

\begin{tabular}{cccc}
\hline Grup & Pretes & Perlakuan & Postes \\
\hline Kelas Eksperimen & $0_{1}$ & $X_{1}$ & $O_{2}$ \\
\hline Kelas Kontrol & $0_{3}$ & $X_{2}$ & $0_{4}$ \\
\hline
\end{tabular}

Untuk melihat efektivitas pengaruh model Problem Based Learning dan model Problem Solving menggunakan analisis normalitas gen (N-gain) dengan persamaan :

$$
\text { N-Gain }=\frac{\text { Spostes }- \text { Spretes }}{\text { Smax }- \text { Spretes }}
$$

Populasi dalam penelitian ini diambil dari Gugus Kartini, Kecamatan Bergas, Kabupaten Semarang. Sampel yang dipilih yaitu 28 peserta didik kelas 4 SD Negeri Bergas Kidul 03 dan 21 peserta didik kelas 4 di SD Negeri Bergas Kidul 04. Langkah-langkah yang digunakan dalam penelitian ini diantaranya: melakukan observasi pembelajaran di kelas, hal ini bertujuan untuk mengetahui budaya pembelajaran yang dilakukan pada sekolah tersebut. Memberikan soal pretes terhadap kelas eksperiman dan kontrol. Pada kelas eksperimen diberi perlakukan menggunakan model Problem Based Learning dan kelas kontrol menggunakan model Problem Solving. Setelah diberi perlakuan yang berbeda, kelas eksperimen dan kontrol diberikan soal postes.

Teknik pengumpulan data menggunakan observasi yang digunakan untuk mengenal kelas dalam melakukan proses pembelajaran. Instrumen yang digunakan adalah lembar observasi guru dan peserta didik. Teknik tes yang digunakan untuk mengetahui kemampuan pemecahan masalah peserta didik berupa mengerjakan soal tes uraian. Pengumpulan data dilakukan dengan: menyusun kisi-kisi, instrumen penelitian, soal, melakukan uji validitas dan reliabilitas, melakukan observasi, memberikan soal pretes, memberikan perlakuan, memberikan soal postes, dan melakukan analisis data yang diperoleh.

Teknik analisis data dilakukan dengan SPSS 20 For Windows. Analisis data deskriptif, analisis prasyarat diantaranya uji normalitas, uji homogenitas, dilanjutkan dengan uji beda ratarata dengan independent sample T-test dan uji N-gain. Uji normalitas yang digunakan ialah ShapiroWilk. Keefektivan model Problem Based Learning dan Problem Solving terhadap kemampuan pemecahan masalah peserta didik dilihat uji beda rata-rata dengan menggunakan Independent Sample T-test. Kemudian di lakukan uji hipotesis. 


\section{Hasil dan Pembahasan}

\section{Hasil}

Analisis Proses Pembelajaran.

Proses pembelajaran yang dilaksanakan dari kelas eksperimen dan kelas kontrol tidak memiliki perbedaan yang terlalu signifikan. Langkah pembelajaran dari masing- masing model dilakukan sesuai dengan analisis langkah pembelajaran menurut ahli. Kedua model memiliki tahapan yang berbeda salah satunya pada model pembelajaran Problem Solving terdapat langkah merumuskan hipotesis sedangkan model Problem Based Learning tidak. Kedua langkah model pembelajaran sejalan dengan indikator kemampuan pemecahan masalah yang akan dikembangkan. Presentase keterlaksanaan model pembelajaran PBL sebesar 93\% sedangkan model pembelajaran PS sebesar $91 \%$.

Analisis Hasil Belajar.

Berdasarkan hasil analisis deskriptif yang digunakan untuk mengetahui perbedaan hasil tes yang dilakukan diperoleh data komparasi hasil pengukuran tes sebelum dilakukan perlakuan (pretes) dan tes sesudah diberi perlakuan (postes) kemampuan pemecahan masalah matematika yang disajikan dalam tabel 2.

Tabel 2. Komparasi Hasil Pengukuran Kemampuan Pemecahan Masalah Matematika

\begin{tabular}{cccc}
\multirow{2}{*}{ Pengukuran } & \multicolumn{2}{c}{ Rata-rata Skor (mean) } & Selisih \\
\cline { 2 - 3 } & Eksperimen & Kontrol & \\
\hline Pretes & 69,43 & 61,05 & 8,38 \\
\hline Postes & 81,50 & 73,43 & 8,07 \\
\hline
\end{tabular}

Berdasarkan data komparasi rata-rata skor pretes kelas eksperimen yang diberi perlakukan model Problem Based Learning dan kelas kontrol yang diberi perlakuan Problem Solving terdapat selisih sebesar 8,38. Sedangkan rata-rata skor postes antara kelas eksperimen dan kelas kontrol terdapat selisih sebesar 8,07. Adapun komparasi diagram kedua kelas kelas disajikan dalam bentuk gambar:

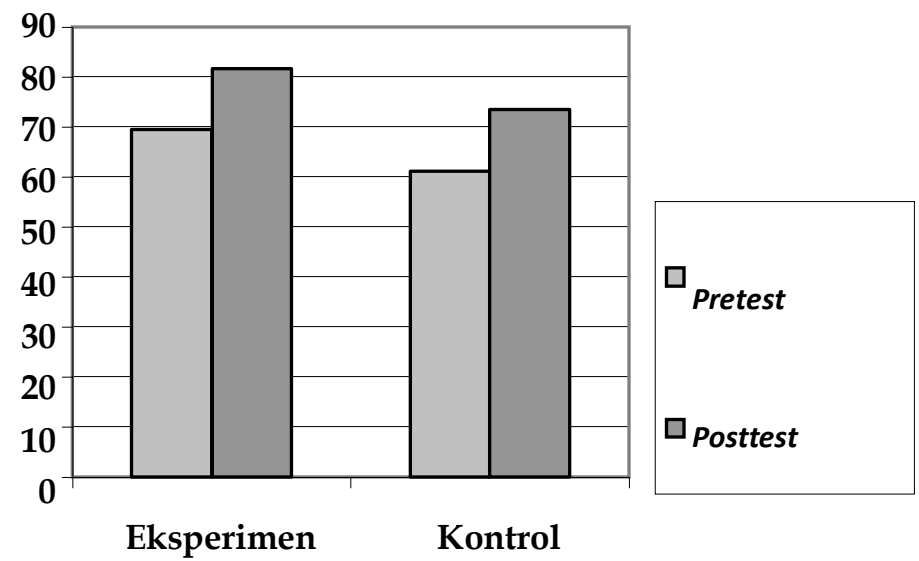

Gambar 1. Diagram Komparasi Hasil Pretest dan Posttest

Berdasarkan gambar diagram di atas, terdapat peningkatan hasil pretes dan postes pada kelas eksperimen yang dengan model Problem Based Learning dan kelas kontrol dengan model Problem Solving. 
Dilakukan uji normalitas yang disajikan pada tabel 3 dan uji homogenitas disajikan pada tabel 4 dan 5 .

Tabel 3. Uji Normalitas Kelas Eksperimen dan Kelas Kontrol

\begin{tabular}{|c|c|c|c|c|}
\hline \multicolumn{5}{|c|}{ Shapiro-Wilk } \\
\hline Hasil & Kelas & Statistics & df & Sig. \\
\hline \multirow{4}{*}{$\begin{array}{l}\text { Te } \\
\text { s Kemampuan } \\
\text { Pemecahan } \\
\text { Masalah }\end{array}$} & Pretes PBL & .941 & 28 & .115 \\
\hline & Postes PBL & .949 & 28 & .182 \\
\hline & Pretes PS & .961 & 21 & .532 \\
\hline & $\begin{array}{l}\text { Postes } \\
\text { PS }\end{array}$ & .925 & 21 & .108 \\
\hline
\end{tabular}

Dari tabel hasil uji normalitas pretes dan postes dari kelas eksperimen maupun kelas kontrol dengan teknik Shapiro-Wilk dapat dikatakan berdistribusi normal karena hasil sig > 0,05. Dari data diatas diketahui perolehan hasil pretes dan postes signifikan $>0,05$ maka dapat disimpulkan bahwa data berdistribusi normal.

Tabel 4. Uji Homogenitas Sebelum perlakuan

\begin{tabular}{llllll}
\hline & & $\begin{array}{l}\text { Levene } \\
\text { Statistic }\end{array}$ & df1 & df2 & Sig. \\
\hline $\begin{array}{l}\text { Hasil Tes } \\
\text { Kemampuan } \\
\begin{array}{l}\text { Pemecahan } \\
\text { Masalah }\end{array}\end{array}$ & Based on Mean & .427 & 1 & 47 & .516 \\
\cline { 2 - 6 } & Based on Median & .315 & 1 & 47 & .577 \\
\cline { 2 - 6 } & $\begin{array}{l}\text { Based on Median and } \\
\text { with adjusted }\end{array}$ & .315 & 1 & 41,648 & .578 \\
& $\underline{\mathrm{df}}$ & & & & \\
& $\begin{array}{l}\text { Based on trimmed } \\
\text { Mean }\end{array}$ & .390 & 1 & 47 & .536 \\
\hline
\end{tabular}

Tabel 5. Uji Homogenitas Setelah Perlakuan

\begin{tabular}{llcccc}
\hline & & $\begin{array}{c}\text { Levene } \\
\text { Statistic }\end{array}$ & df1 & df2 & Sig. \\
\hline $\begin{array}{l}\text { Hasil Tes } \\
\text { Kemampuan }\end{array}$ & Based on Mean & 1.052 & 1 & 47 & .310 \\
\cline { 2 - 6 } $\begin{array}{l}\text { Pemecahan } \\
\text { Masalah }\end{array}$ & Based on Median & .922 & 1 & 47 & .342 \\
\cline { 2 - 6 } & $\begin{array}{l}\text { Based on Median and } \\
\text { with adjusted } \\
\text { df }\end{array}$ & .922 & 1 & 42,316 & .342 \\
& $\begin{array}{l}\text { Based on trimmed } \\
\text { mean }\end{array}$ & .929 & 1 & 47 & .340 \\
\hline
\end{tabular}

Dari Tabel 4 diketahui hasil uji homogenitas kelas eksperimen dan kelas kontrol sebelum diberikan perlakuan menghasilkan sig 0,516 > 0,05 yang mengartikan bahwa kedua kelas homogen. Sedangkan hasil Tabel 5 diperoleh hasil homogenitas setelah diberikan perlakuan dari kelas eksperimen maupun kelas kontrol menghasilkan sig 0,310 dimana > 0,05 yang mengartikan bahwa kedua kelas memiliki varian yang sama atau homogen. 
Setelah melakukan uji prasyarat dapat disimpulkan bahwa data penelitan berdistribusi normal dan hasil tes kemampuan pemecahan masalah sebelum dan sesudah diberi perlakuan terdapat varian yang sama atau dikatakan homogen dilakukan uji T (Idenpendent sample T-Test). Hasil analisis uji T disajikan dalam bentuk Tabel 6.

Tabel 6. Hasil Analisis Uji T dengan Independent Sampel T-Test

\begin{tabular}{|c|c|c|c|c|c|c|c|c|c|c|}
\hline Levene & Test for Eq & lity of & & & T-test & $r$ Equ & lity of 1 & eans & & \\
\hline & & $\mathbf{F}$ & Sig. & $\mathbf{t}$ & df & $\begin{array}{l}\text { Sig. } \\
(2- \\
\text { tail }\end{array}$ & $\begin{array}{l}\text { Mean } \\
\text { Differ } \\
\text { ence }\end{array}$ & $\begin{array}{l}\text { Std. } \\
\text { error } \\
\text { Differ }\end{array}$ & $\begin{array}{l}95 \% \mathrm{C} \\
\text { Interv } \\
\text { the Di }\end{array}$ & $\begin{array}{l}\text { idence } \\
\text { of } \\
\text { ence }\end{array}$ \\
\hline & & & & & & ed) & & ence & Lower & Upper \\
\hline $\begin{array}{l}\text { Hasil Post- } \\
\text { Test }\end{array}$ & $\begin{array}{l}\text { Equal } \\
\text { variances }\end{array}$ & 1.052 & .310 & 3.478 & 47 & .001 & 8.071 & 2.321 & 3.402 & 12.741 \\
\hline Kemampuan & assumed & & & & & & & & & \\
\hline $\begin{array}{l}\text { Pemecahan } \\
\text { Masalah }\end{array}$ & $\begin{array}{l}\text { Equal } \\
\text { variances }\end{array}$ & & & 3.364 & 37.188 & .002 & 8.071 & 2.399 & 3.210 & 12.932 \\
\hline & $\begin{array}{l}\text { not } \\
\text { assumed }\end{array}$ & & & & & & & & & \\
\hline
\end{tabular}

Berdasarkan output di atas diperoleh nilai signifikasi (2-taled) sebesar 0,001 < 0,05 maka dapat disimpulkan bahwa terdapat perbedaan rata-rata hasil belajar peserta didik antara model pembelajaran Problem Based Learning dengan Problem Solving. Untuk memperkuat hasil uji independent sample T-test dilakukan uji normalitas gain (N-Gain):

$$
\mathrm{N}-\text { Gain }=\frac{\text { Spostes }- \text { Spretes }}{\text { Smax }- \text { Spretes }}
$$

\begin{tabular}{|c|c|c|c|}
\hline \multirow[t]{3}{*}{ Keterangan : } & \multirow[t]{3}{*}{$\begin{array}{l}S \text { postes } \\
S \text { pretes } \\
S \text { max }\end{array}$} & \multicolumn{2}{|c|}{$\begin{array}{l}\text { : skor postes } \\
\text { : skor pretes } \\
\text { : skor maksimum ideal }\end{array}$} \\
\hline & & Batasan & Kategori \\
\hline & & $\begin{aligned} \mathrm{g} & >0,7 \\
0,3 & <\mathrm{g} \leq 0,7 \\
\mathrm{~g} & <0,3\end{aligned}$ & $\begin{array}{l}\text { Tinggi } \\
\text { Sedang } \\
\text { Rendah }\end{array}$ \\
\hline
\end{tabular}

Berdasarkan hasil uji N-gain kelas eksperimen meningkat sebesar 0,3714, dalam kategori sedang. Dibandingkan dengan hasil kelas eksperimen, uji N-Gain dari kelas kontrol meningkat sebesar 0,3052. Kedua hasil tersebut meningkat dalam kategori sedang. Sehingga peningkatan lebih tinggi terjadi pada kelas eksperimen dengan model Problem Based Learning.

\section{Pembahasan}


Hasil efektivitas dari kedua kelas, dilakukan untuk menguji hipotesis. Pengujian hipotesis dilakukan untuk menentukan apakah hipotesis diterima atau ditolak.

$H_{o}$ : Tidak terdapat perbedaan kemampuan pemecahan masalah yang signifikan dari penerapan model Problem Based Learning dan Problem Solving dalam pembelajaran matematika kelas IV SD. $H_{a}$ : Terdapat perbedaan kemampuan pemecahan masalah yang signifikan antara dari model Problem Based Learning dan Problem Solving dalam pembelajaran matematika kelas IV SD.

Hasil output uji Independent Sample T-Test pada Tabel 7 diketahui bahwa nilai signifikasi 2tailed sebesar 0,001 yang artinya lebih kecil dari 0,05 maka $\mathrm{H}_{\circ}$ ditolak dan $\mathrm{H}_{a}$ diterima. Karena $\mathrm{H}_{\mathrm{o}}$ ditolak dan $\mathrm{H}_{\mathrm{a}}$ artinya terdapat perbedaan efektivitas antara model Problem Based Learning dan Problem Solving terhadap kemampuan pemecahan masalah matematika peserta didik kelas IV SDN Bergas Kidul 03 dan SDN Bergas Kidul 04 Kecamatan Bergas Kabupaten Semarang Semester II Tahun Pelajaran 2019/2020. Keberhasilan model PBL yang efektif meningkatkan kemampuan pemecahan masalah matematika peserta didik dipengaruhi oleh kegiatan pembelajaran yang dilaksanakan dengan mengorientasi peserta didik pada masalah hingga masalah tersebut dipecahkan. Pembiasaan pembelajaran dengan model tersebut dapat meningkatkan kemampuan pemecahan masalah matematika denga efektf. Sejalan dengan Hung dalam Astuti, Slameto, dan Setyaningtyas (2018) yang menyatakan bahwa dengan mengharuskan peserta didik memecahkan masalah sebagai format utama instruksi dalam pembelajaran, PBL dapat meningkatkan kemampuan dan ketrampilan dalam menerapkan pengetahuan, memecahkan masalah, mempraktekkan pemikiran tingkat tinggi dirinya sendiri. Hasil ini memperkuat penelitian yang dilakukan oleh Yusri (2018) yang menghasilkan bahwa diterapkannya model pembelajaran Problem Based Learning dapat meningkatkan kemampuan pemecahan masalah peserta didik. Begitu juga penelitian yang dilakukan oleh Indarwati, Wahyudi, \& Ratu, (2017) menyatakan bahwa melalui penerapan model Problem Based Learning berpengaruh terhadap kemampuan pemecahan masalah pada peserta didik. Penelitian yang dilakukan oleh Ruchhaedi, Suryadi, dan Herman (2015) yang menghasilkan bahwa model pembelajaran PBL dapat meningkatkan kemampuan strategi heuristik pemecahan masalah matematis yang lebih baik.

\section{Simpulan}

Dari hasil penelitian dan pembahasan, maka dapat ditarik kesimpulan bahwa terdapat perbedaan kemampuan pemecahan masalah matematika peserta didik penerapan model pembelajaran dengan PBL yang lebih lebih efektif jika dibandingkan dengan model pembelajaran Problem Solving dalam materi pembulatan dan penaksiran dua bilangan cacah maupun pecahan. Keberhasilan model pembelajaran PBL dapat dilihat dari rata-rata peningkatan nilai hasil postes menjadi 81,50 dengan skor N-gain yang mengalami peningkatan sebesar 0,3714 termasuk dalam kategori sedang. Sedangkan model pembelajaran Problem Solving mengalami peningkatan ratarata hasil postes menjadi 73,43 dengan nilai N-gain sebesar 0,3052 termasuk dalam kategori sedang. Kedua hasil tersebut meningkat dalam kategori sedang. Sehingga peningkatan lebih tinggi terjadi pada kelas eksperimen dengan model Problem Based Learning. Sehingga ditarik kesimpulan model pembelajaran Problem Based Learning lebih efektif untuk meningkatan kemampuan pemecahan masalah matematika pada peserta didik kelas IV SD.

Hasil penelitian menunjukkan model pembelajaran PBL dapat meningkatkan kemampuan pemecahan masalah matematika peserta didik kelas 4 SD, maka disarankan penggunaan model pembelajaran PBL dapat dibiasakan dan dikembangkan untuk pembelajaran matematika di kelas 
karena pembelajaran berbasis pemecahan masalah penting untuk membekali peserta didik agar terbiasa memecahkan masalah.

\section{Daftar Rujukan}

Abidin.(2014). Desain Sistem Pembelajaran dalam Konteks Kurikulum 2013. Bandung: Refika Aditama.

Anugraheni, I. (2018). Pengembangan Perangkat Pembelajaran Matematika Berbasis Pendidikan Karakter Kreatif di Sekolah Dasar. Refleksi Edukatika, 8(2).

Arifin, Zainal. (2014). Evaluasi Pembelajaran. Bandung: PT Remaja.

Astuti, D. A. P., \& Slameto, E. W. S. (2018). Pengaruh Penerapan Model Problem Solving Terhadap Kemampuan Pemecahan Masalah Peserta didik Kelas IV SD. Didaktika Dwija Indria, 6(3).

Astuti, W. P. (2018). Efektivitas Model Pembelajaran Problem Based Learning dan Problem Solving Terhadap Kemampuan Berpikir Kreatif Matematika Peserta didik Kelas 4. Jurnal Imiah Pendidikan Dan Pembelajaran, 2(2), 159-166. https://doi.org/10.23887/jipp.v2i2.15349

Faizah, U. (2015). Penerapan Pendekatan Saimtifik Melalui Model Project Based Learning untuk Meningkatkan Keterampilan Proses dan Hasil Belajar Peserta Didik Kelas IV SD Negeri Seworan, Wonosegoro. Jurnal Scholaria, 5(1), 24-38.

Gulo, W. (2002). Strategi Belajar Mengajar . Jakarta: PT. Grasindo.

Haji, S. (2010). Pendekatan Problem Posing dalam Pembelajaran Matematika di Sekolah Dasar. Kependidikan Triadik, 5(1412), 1-72

Hidayat A. dan Irawan I. (2017). Pengembangan LKS Berbasis RME dengan Pendekatan Problem Solving untuk Memfasilitasi Kemampuan Pemecahan Masalah MatematisPeserta Didik. Journal Cendekia: Jurnal Pendidikan Matematika, 1(2), 51-63.

Indarwati, D., Wahyudi, W., \& Ratu, N. (2017). Peningkatan Kemampuan Pemecahan Masalah Matematika Melalui Penerapan Problem Based Learning untuk Peserta Didik Kelas V Sd. Satya Widya, 30(1), 17. https:/ / doi.org/10.24246/j.sw.2014.v30.i1.p17-27

Nasir, M. (2016). Penelitian Efektivitas Model Pembelajaran Berbasis Masalah ( Problem Based Learning ) Terhadap Kemampuan Pemecahan Masalah Peserta didik Pada Pelajaran Matematika. Madrasah Ibtidaiyah, 1(2), 1-19. Retrieved from https://ojs.uniska bjm.ac.id/index.php/jurnalmuallimuna/article/view/381.

Nurhadi. (2003). Pendekatan Kontekstual. Jakarta: Departemen Pendidikan Nasional.

Permendikbud No 22 Tahun 2016 
Rosdakarya. Dahar, R. W. (2011). Teori-Teori Belajar dan Pembelajaran. Jakarta: Erlangga.

Ruchaedi, D., Suryadi, D., \& Herman, T. (2015). Pengaruh Problem Based Learning (PBL) terhadap Kemampuan Heuristik Pemecahan Masalah dan Sikap Matematis Peserta didik Sekolah Dasar. EduHumaniora | Jurnal Pendidikan Dasar Kampus Cibiru, 7(1). https://doi.org/10.17509/eh.v7i1.2792.

Rusman. (2012). Model-model Pembelajaran (Mengembangkan Profesionalisme Guru Edisi Kedua).Jakarta: Raja Grafindo Persada.

Sugiyono. (2015). Metode Penelitian Pendidikan. Bandung: Alfabeta.

Suyono dan Hariyanto. (2015). Belajar dan Pembelajaran. Bandung: PT Remaja Rosdakarya.

Undang-Undang sisdiknas No. 20 Tahun 2013

Wahyudi dan Anugraheni I. (2017). Strategi Pemecahan Masalah Matematika. Salatiga: Satya Wacana University Press.

Yusri, A. Y. (2018). Pengaruh Model Pembelajaran Problem Based Learning Terhadap Kemampuan Pemecahan Masalah Matematika Peserta didik Kelas VII Di SMP Negeri Pangkajene. Mosharafa: Jurnal Pendidikan Matematika, 7(1), 51-62. https://doi.org/10.31980/mosharafa.v7i1.341. 